\section{Educational Cable TV in Alberta}

Catherine E. Gordey

Catherine E. Gordey is an Associate Director of the Alberta Educational Con 10 programming are broadcast over educational programming schedule. Each system is an independent organization, a consortium, playdependent
ing prog
public.
Progr

Programs can range from "People in Power" produced by Canadian Cable Sys tems, to the Esso Resources series, "The
Newcomers," in both English and French; or from a college's photography series to "Car ACCESS, Alberta's provincial agency producing educational programs. Programs a chosen or produced by an educational cable community. The background of education cable consortia began with the formation of the Canadian Raduo and Television

Nationally

In 1967, the Broadcasting Act established he CRTC and recommended that "facilitics broadcasting system for educational broa casting." In 1970, this recommendation was tional broadcasting to be under the jurisdic tion of a provincial government authority.
At this time, the definition of "educational

Educational programming is programming

to provide learning opportunities

or the acquisition or improvement

of knowledge,

and subject to supervision by the provincial authority;
and programming providing information on courses of
instruction

or broadcasting of special events Two years later, another federal direction, P.C. 1972-15 clarified that this one education channel should be licensed through a provincorporation. This allowance for an independent corporation was for the benefit of Ontario Education Communication Authority (OECA) which alration producing and broad casting educational programming.

Provincially
In Alberta on August 1, 1970, in response
In Alberta, over 150 hours of educational educational cable system is not on the same strengthened to state that every cable con to the CRTC ruling for an educational chan der established the Alberta Education Communications Authority (AECA) to be responsible for overseeing transmission, pro dional communications. The authority con sists of the minister of education, the minit ter of advanced education and manpowe and the associate minister of telephones deputy ministers of these three department and an executive director. The role of the authority is to administer the Alberta Educa tional Communications Corporation A priorities to be met by ACCESS through th acquisitions and production of both educa tional programs and other materia designate all educational television chann vice on technical and other problems r to the use of communications technology. It is the belief of the AECA that "dect ions with respect to the use of cable for eth (a) covered by the cable system or syster icensed to serve that area". (Morton, 1971 Therefore, the authority designates educational channels in the province and organizational and administratic framework which best suits its own need Besides designating cable consortia as the AECA role in regard to cable program ing is to:

supervise and assess by any appropt ate means the programs and mat als transmitced by the consortia; CESS, the major distributor of $\mathrm{e}$ cational programming in the pro

.... a ministerial order estab. ished the Alberta Educational Communications Authority (AERA) to be responsible overseeing transmission, produ tion, and policies in regards educational communications. What is a Consortium?

The authority may recognize in each calt geographic area a consortium of educational purpose of using cable for educational purposes with the cooperation of the cable sys em owner or operato. All ed calional instunder the jurisdiction of the minister ducation or the minister of advanced educa tion and manpower are entitled to becom participants (i.e., full members) in a consoand Drug Abuse Commission (AADAC) or community associations interested in furthering their educational programs may bection Interest to form an initiates sortium usually originates in a local educaional institution which then contacts all other educational institutions operating in hip would prepare a memorandum of agrerevenues, programming, operation and the term of the agreement. Once prepared, this its information.
Membership structures and fees are those institutions governed under the ministers of education can be voting, or full memis always within the hands of the control institutions School districts, community and and universities usually form the base of the "... the authority designates all educational channels in the province and expects that each consortium will establish the organizational and administrative framework which best suits its own need."

consortium. Areas not served by a local university are still within the jurisdiction of Athabasca University and may also be it is to deliver higher education opportunites to these areas. Further education councils are also likely members for the cable consorTable 1

\begin{tabular}{|c|c|c|c|c|}
\hline & & Alberta Consortia & & \\
\hline & MEMBERSHIP & STAFF & HEAD END/STUDIO & $\begin{array}{l}\text { PROGRAMMING } \\
\text { (March 1981) }\end{array}$ \\
\hline $\begin{array}{l}\text { cetc } \\
\text { Calgary }\end{array}$ & $\begin{array}{l}1 \text { School Board } \\
1 \text { College } \\
1 \text { Institute } \\
2 \text { Universities }\end{array}$ & $\begin{array}{l}1 \text { Co-ordinator } \\
2 \text { Part-time Operators }\end{array}$ & $\begin{array}{l}\text { SAIT/access to } \\
\text { SAIT studio }\end{array}$ & $\begin{array}{c}57 \\
\mathrm{hr} / \mathrm{wk}\end{array}$ \\
\hline $\begin{array}{l}\text { eecc } \\
\text { Edmonton }\end{array}$ & $\begin{array}{l}2 \text { School Boards } \\
1 \text { College } \\
2 \text { Universities } \\
4 \text { Others }\end{array}$ & $\begin{array}{l}\text { 1/4 Manager } \\
2 \text { Operators }\end{array}$ & $\begin{array}{l}\text { Warehouse/access to } \\
\text { School Board studio } \\
\text { in the same building }\end{array}$ & $\begin{array}{c}72 \\
\mathrm{hr} / \mathrm{wk}\end{array}$ \\
\hline $\begin{array}{l}\text { fincec } \\
\text { Fort McMurray }\end{array}$ & $\begin{array}{l}3 \text { School Boards } \\
1 \text { College } \\
1 \text { University } \\
1 \text { Other }\end{array}$ & IN TRANSITION STAGE & & \\
\hline $\begin{array}{l}\text { gpeecc } \\
\text { Grande Prairie }\end{array}$ & $\begin{array}{l}1 \text { School Board } \\
1 \text { College } \\
1 \text { University } \\
\end{array}$ & $\begin{array}{l}1 \text { Co-ordinator/Operator } \\
1 \text { Part-time Operator }\end{array}$ & $\begin{array}{l}\text { Junior High School/ } \\
\text { new studio in school }\end{array}$ & $\begin{array}{c}24 \\
\mathrm{hr} / \mathrm{wk}\end{array}$ \\
\hline $\begin{array}{l}\text { Spec } \\
\text { St. Paul }\end{array}$ & 4 School Boards & $\begin{array}{l}1 \text { Co-ordinator } \\
2 \text { Programmers } \\
\text { 1 Student Operator } \\
1 \text { Part-time Secretary }\end{array}$ & $\begin{array}{l}\text { Regional High School/ } \\
\text { own studio in school }\end{array}$ & $\begin{array}{c}6 \\
\text { hr/wk }\end{array}$ \\
\hline $\begin{array}{l}\text { ycet } \\
\text { Edson }\end{array}$ & 1 School Board & $\begin{array}{l}1 \text { Part-time School } \\
\text { Technician }\end{array}$ & $\begin{array}{l}\text { High School/new } \\
\text { studio in school }\end{array}$ & occasional \\
\hline
\end{tabular}

Other institutions, organizations and groups may be granted associate memberRed Cross,

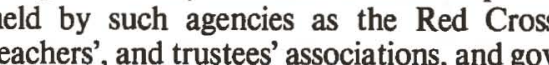
(iberta Alcoholism nd Drug Abuse Commission (AADAC). by the channel and on the amount of use made by each member as well as its ability to

Donations are welcome from any source, and several consortia have become or are in society under the Societies Act so that don tions can be tax deductible. No funding to date has been given to the consortia by the provincial government, although a request
has been made and is being considered. Board of Directors

Representatives from Bitution com 作 or the consortium. The board has the authority to appoint an agent board to ma ge the logistics of the cable operation. 
Agent Board

erations of the consortium that the board of directors deems necessary, for example:

1 . installing and maintaining head end

equipment,

providing the necessary physical

3. looking after finances,

4. providing and supervising the$$
\text { Program Coordinator }
$$

The board of the consortium usually desig. nates an educator to act as program coor-
dinator. This person may work alone or, as some consortia have done, may organize program committees to be responsible for
evaluating and answering program needs.

Animateur
Another possible employee of a cable consortium is an animateur, operator, or coordinate the activities of the consortium. This person is able to have a broad perspec tive over the whole operation and be the contside agencies and the

Programming

cable channel to a grants the educational consortium sends program logs each month to the AECA as a way of informing the AECA of program content and general operation of the channel. Following
guidelines developed by the CRTC, AECA recommends procedures for completing the logs.

Each year using these program logs, the
AECA prepares a study which includes description of each operating consortium in terms of membership, staff, intended audience, and details of programming describing

"This individualization of consortia and the emphasis on loca needs guarantees that educational television is specifically designed to fulfill unique educational needs within a given geographic area."

daily broadcast times, average weekly broadcasting hours, the number of programs
broadcast and the percentages of local, ACother programming and of Cana12
Alberta Consortia

verage in Alberta 1985 that cable will be available in percent of the province. Currently within the proble Fort McMurray, Grande Prairie and S. Paul; and at least three more in the form tive stages in Drumheller, Lacombe, and
Vegreville. See Table 1 for a synopsis Vegrenle. See Table 1 for a synopsis facilities, and average programming hour
per week during March, 1981 .

Programming

政 1. devision, each consortium tries to: tional programs to a large number of people within the community that linked by cable;

2. relate all programming to local needs

3. provide educational institutions and organizations with a means of com-
municating with the general public for example, board meetings an

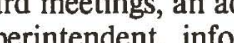
mation about courses offered by in-

4. provide direct and convenient access to instructional and information

provide assistance for efficient an medium of television.

This individualization of consortia and the emphasis on local needs guarantees the to fulfill unique educational needs within given geographic area. While having the ducational cable consortia can and shoul

"At present, cable coverage in Alberta is approximately 70 percent with a prediction for 1985 that cable will be available in 85 percent of the province."

afford the luxury of appealing to a narrow
audience for a variety of programs. Proaudience for a variety of programs. Prolocal needs are insurance towards ineresting, satisfying and maintaining a loca audience.
Politics to car main

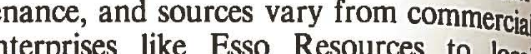
school boards. Local productions are en couraged because of their ability to react (t) ncial production agency) varies for worldwide appeal like "Science Intern tional" to more Canadian-specific materials . several popular programs. The Southern Alberta Institute of Technology (SAIT) hasa basic photography course that has been Gared course for library technicians which has been broadcast by northern consortia, where this type of course is not available through the which is to onty. A mandate and thus is a member of each of the consortia, offers the video part of some of its courses over cable. If cable is not received in a school to view the pros a local colbe With the varticipatiogram ocal educational institutions, including com. munity schools, educational consortia, and program a new channel at least 10 hours per week and develop it over a few years into a 30 to 40 hours week. This year's study of the educational cable consortia, based on the dicates worthwhile efforts in local program ming. The cable ents in local program Prairie has achieved great success in the form of three busy phone lines during the daily hour-long production, "Our Plaw added near the end of the 1980-1981 proramming year in an attempt to keep with the demand. The study reports that monton's educational cable consortium con s school board members take advantage of the communications opportunity to inform their rate payers of school board activitien The report recommends that more oppor deal with "hot" issues of interest to edin deal with hol issues of interest to edulu.
tion in the communities served by cable. References

Morton R. Policy paper for the Alberta Ed manda Young is a professor of com Edmonton: ACCESS, 1977 .

\section{Community Communication: Parent Education Radio Program}

Wanda Young

Davis and Baran (1981) credited ministrative research in communication, through the establishment of marketing
research and audience analysis. In this stud audience analysis was applied in a survey of whether a particular need of audiences was being met by the stations. The main topic of concern was paren that the groups most in (1978) stated education were those who do not yet have children, those who no longer have children, and those who will never have children. In dicated that North Amorican civrenner in quired a social policy and social practices hat would give status and approval to medisood. Brontenbrenner recommended ing where children are, what they are doing and who cares for them. The conditions of the children and their caretakers should be

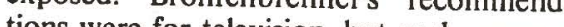
ming could be applied to radio as programelderly and single persons, the audiences that Brontenbrenner recommended.

do not yet have childresent a group who have unwanted pregnancies (Alan Guttmacher Institute, 1976). Buck (1971) found
that 98 percent of teenagers listen to radio that 98 percent of teenagers listen to radio,
spending two hours per day (Dominick, A group who no longer have children are
the elderly. Foster (1970) and Robbins (1971) the elderly. Foster (1970) and Robbins (1971) noted that the elderly used radio extensively
and were loyal listeners. The adult listening audience might assist in establishing status for parenthood. Men-
delsohn (1971) observed that radio plays an important part in the everyday life of many
persons. In Canada, 98.4 percent of all persons. In Canada, 98.4 percent of all
households have one or more radios (Segal, 1980).

The purpose of this study was to survey Canadian radio stations for programming questions of interest were: Which Canadian radio stations offered programs in parent education?

What kinds of program were produced?

Background of the Study

In a study of parenting education re(Hources in the province of Saskatchewan recommended that radio programs dealing visory board and ststion schiped. The adthe University of Saskatchewan FM radio station, asked for suggestions for educational radio programs. A series on parent education the Health Promotion Directorate to start the project in 1980. was defined as the preparation of parents and

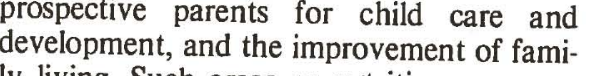
ment of resources, environment, and relaonships were of particular concern. objective of many of the parent eduas an programs reported by Crooke and Glover (1977) in a history of the subject. Breivagel and Parker (1980) pointed out that families ing countries may be more advanced in programming to help families (Clearinghouse on Development Communication, 1980). In flitt with therica, media programs often consexual restraint lifetime planning for the future (Le Masters, 1970). schramm (1974) defined communication as an orientation to a set of informational signs y. The Simon Fraser University Tertain munications Research Group (1978) observed that it was a purpose of programming promote social change and development, parents. Whatever inedia or mh as those of used to communicate parent education concepts, evaluation was needed as to the effectiveness of the program in meeting the Tanabe, 1980; Crooke and Glover, 1977). 